Indonesian Journal of EFL and Linguistics

Vol. 5 No. 2, 2020

eISSN: 2503-4197, pISSN: 2527-5070

www. indonesian-efl-journal.org

\title{
An Analysis of Translation Strategies of Honorific Term in the Film "The Boss Baby"
}

\author{
Aisya Novita Sari \\ Universitas Negeri Yogyakarta \\ e-mail: aisyanovita.2018@student.uny.ac.id \\ Zamzani \\ Universitas Negeri Yogyakarta \\ e-mail: zamzani_55@yahoo.com
}

\begin{abstract}
:
Translation helps the people to communicate and to transfer the information given by others. In translation language and meaning is the key of those communication and information. The culture of each language is different from another. Honorific is one of the cultures in language. The aims of the study is to examine the translation strategy of honorific term in the film The Boss Baby in its English to Indonesian translation and the use of the honorific. In this research, the researchers mainly used the qualitative research design in the strategy of descriptive. The subject of his research is honorific. Meanwhile, the data or object is the translation of subtitle of the film The Boss Baby. The method and technique in collecting data is observation specifically in noting technique and the technique for analyzing data is identity method. Research instrument is human instrument. Based on the findings, there are six types of translation strategies used. Those six types are literal translation, naturalization, generalization, reduction, transposition, and linguistic compression. The most used translation strategy is literal translation and the least one is transposition.
\end{abstract}

Keywords: honorific term, subtitle, translation, translation strategy 
Aisya Novita Sari \& Zamzani

\section{INTRODUCTION}

Conversation is one of the keys to communicate with others. The problem which may occur in a conversation is that when the speaker and the listener do not uses the same language. If that happened, people cannot just know what the meaning the speaker wants to deliver to the listener. Well, there could be a way by using gestures. However, not all of them, the messages, can be gestured. This is really problematic. For a case like that, the solution is by translating.

Translation helps the people to communicate. Translation helps people to transfer the information given by others. It can even also support the transibility of metaphors (Sambayu, 2019) and then it can become useful reference in translating a song (Hendra, 2019). The translation covers many kinds of translation. It can be a case of formal document, non-fiction book, fiction book, and subtitling. In this sophisticated era, we can even found easy translation application or a translated document online. For the document which has been translated, of course, and it is not only in English language.

In translation, there are two aspects to take into consideration. They are source language and target language. Source language is the source or the original of the language which needs to be translated. Meanwhile, target language is the target or to what language the original language wants to be translated. The relation and the meaning of the source and target language need to be in a harmony since the translation needs to transfer the meaning and information from the source to target language. Related to that, language choices need to take into consideration. Fasold (in Rahayu \& Fauzan, 2020) proposed that review on language choice in based on three approaches, namely sociological, social and anthropological approaches. Further, the context also included as important aspect since it can differentiate the meaning (Ahdillah, Hartono, \& Yuliasri, 2020).

As discussed above the translation in this era is easy to be found and as it easy to be found, people somehow always seek for the fastest one. The fastest translation, commonly, can be found online. For example, nowadays, we can find various subtitles from online. Subtitle is written translation which commonly placed on the foot of the screen (Manullang \& Marpaung, 2020). It is used to assist the audience of target language to comprehend the movie plots (Qiuyang \& Yingli, 2020). Translated subtitles from online sources are usually translated by fans or a translator who wants to translate them. Subtitles that are generally translated into various languages are subtitles from English. Given that English is an international language and many people have mastered it other than native speakers.

When discussing international language, English also has a culture and this is reflected in the language. English speakers speak differently from people of different social status. They can be said to have 'rules' in their language. In general, like other narrative, this is related to politeness, term of address, or honorific, regarding the way people talk to others. According to Mansor, Rahim, Mamat, and Halim (2018), the 
culture's rules of politeness have connection with the use of address terms in certain culture. However, the question is how those rules can be translated into other languages. Related to that question, the researcher has an interest in researching the strategies used by the translator to translate it.

As the research need subject, the researcher choose the source of data from the fiction one. The work of fiction that will be analyzed is a film with subtitles as the foc us. The subtitles chosen by the researchers are English subtitles and the translation is in Indonesian from the film The Boss Baby, one of the films released in 2017. The Boss Baby tells the story of a baby whose mission is to protect the 'attention' given to babies from another concern of pets of a company called PuppyCo.

Meanwhile, since the related rule mentioned before which connects with politeness, term of address, or honorific is a large field and it could consume much time, the researcher choose to only focus on the honorific term. Regarding honorific, Irvine (1992) mentioned that honorific is 'grammaticalized in a particular language' which means that the expression of honorific is different from one language to another language. The way to express honorific, there are several ways. The differences and ways to communicate makes the translation of honorific terms somehow difficult (Yang, 2010).

Since the purpose of translation is to deliver the information, the meaning is important. Translation strategy is one of the way to get the equivalence of meaning and naturalness of the target language (Salsabila \& Jumanto, 2020) and translation itself can be said as translating culture (Fadhillah, Lubis, Sinar, \& Setia, 2019). In accordance, the researchers would like to examine the translation strategy of honorific term, in its English and Indonesian translation. By doing that, the researcher hopes that the research will give benefit for the people who want to study about the same topic.

\section{LITERATURE REVIEW}

\subsection{Translation}

Based on Nida and Taber (in Tanjung, 2018, p. 3) definition, translation related to reproduce the closest equivalent of the source language message as natural as possible. According to that, translation needs to be sure to transfer the meaning and message of the source language. The meaning and message need to have high equivalency with the source language or in other words it just look like what is written in the source language.

Related to the field, translation is a study in comparative linguistics of linguistics which mainly is about the aspect of semantics (Newmark, 1988, p. 5). Since translation is about semantics, it is have relation in meaning. The meaning here is the meaning in the surface. A meaning which conveyed by the speaker in his/her utterance or by the writer in his/her writing.

In translation, there is this so-called process. The process of translation is, as Newmark's suggestion, operational. Newmark (2001, p. 19) gives some procedures in 
translation. The first thing to do is choosing a method of approach. When translating a text, for example, the translator need to decide what approach he/she wants to use by considering the text and the meaning the writer wants to convey. The second procedure is in which level the translator wants to translate. There are four levels that likely occur. They are the SL (source language) text level, the referential level, the cohesive level, and the level of naturalness. The last procedure is revision procedure. This procedure is needed when the translator wants to check whether the translation is nearly as natural as possible with the source text or not.

When translating, we need some techniques or strategy. Translation strategy can be a tool for the translation which is added with translation model (Volkova, 2014). Some experts in translation field give some techniques for translating. For example, Vinay and Dalbernet (1995, p. 41) who divide two methods in translation, namely direct or literal translation and oblique translation. In the latter discussion, it discussed some techniques on translation. In their suggestion, however, they use the name 'procedure' to relate about how to translate the source language. Those so-called procedures are borrowing, calque, literal translation, transposition, modulation, equivalence, and adaption.

Other than Vinay and Dalbernet, there is also Newmark. In his book entitled "Approach to Translation", there are some translation procedures suggested (Newmark, 2001, p. 30). Those procedures are transcription, one-to-one translation, through-translation, lexical synonymy, componential analysis, transposition, modulation, compensation, cultural equivalence, translation label, definition, paraphrase, expansion, contraction, recasting sentences, rearrangement, improvements, and translation couplet.

Since there are many kind of translation techniques suggested, Molina \& Albir (2002) made a proposal to classify translation technique. That proposal involves some translation techniques. Those techniques and examples which followed below are mostly taken from Molina \& Albir. First is adaptation, a technique which used in translation by adapting the word, for example, that want to be translated from source language into a word in the target language like in the word baseball which may be translated into fútbol in other language. Second, amplification used when there is no equivalence word in the target language like the example of the word Ramadan which becomes Ramadan, the Muslim month of fasting. Third is borrowing, done by borrow the word from the source language and present it as it is in the target language. For example, there is a food called sushi in Japanese and it is translated into sushi in English. The next one is naturalized which done by naturalize the word in source language to the target language like in meeting become mitin. Then, calque, a technique which is translating the source language according to language structure of the target language. For example, the words green leaf in English translated into daun hijau in Indonesian. The following is compensation or word, phrase, or sentence which is translated into the target language which become different in the structure. The following is description. That is translating by describing the translated words. There is 
this example; there is a word panettone which translated into the traditional Italian cake eaten on New Year's Eve. The next one is discursive creation which presents a temporary equivalence which cannot be guessed and sometimes out of context like the case for translating a title (Nababan, 2007). The next one is established equivalent, a technique by giving an equivalent word of phrase in the target language. For example, killing two birds with one stone in English translated into sekali mendayung dua tiga pulau terlampaui in Indonesia. The following are generalization or generalize the word, linguistic amplification, linguistic compression, literal translation, modulation, particularization or particulate a word, reduction or reducing words, substitution or substitute the word, transposition or a change in grammar category, and variation.

Tanjung (2018, p. 14-15) said that the effort of the translators to solve the problem which occurs in their translation process is according to their ideology, whether they focus on the reader of source language or the reader of the target language. The two ideology have the far different description and aspects. Those two ideologies are called foreignization and domestication by Venutti (in Munday, 2016, p. 225). Foreignization, as Venutti (in Munday, 2016, p. 225) described, is 'an ethnocentric reduction of the foreign text to receiving cultural values'. This means that foreignization deals with the translation based or focus on the author or writer. On the other hand, domestication 'entails choosing a foreign text and developing a translation method along lines which are excluded by dominant cultural values in the target language (Venutti in Munday, 2016, p. 225-226). That is means the domestication ideology is a translation which focus on the reader.

\subsection{Honorific}

It said that some honorific expression in languages which has honorific registers, they only used 'by certain people or for certain people (Agha, 1998). Cited from Holmes (2013, p. 14), the use of address term and honorific or the form used to show honor to the other person people speak to (Kridalaksana, 2011, p. 85), in Chinese, Japanese and Korean, is commonly related to social convention or linguistic etiquette. The Japanese honorific itself has a long history (Haugh \& Obana, 2011). Feely, Hasler, and Gispert (2019) said that the honorific speech in Japanese language is used to convey respect, deference, humility, formality and social distance. The Japanese honorific, as Japanese people call it keigo, is divided into three categories. They are addressee honorifics (teineigo), the others are referent honorifics which is divided into sonkeigo (subject honorification) and kenjoogo (object honorification) (Shibatani in Jakobsson, 2016, p.10).

Teineigo or addressee honorific is an expression or language used to indicate a respect to the hearer the speaker speaks to (Wetzel in Jakobsson, 2016, p.11). The teineigo also indicate or occurs in formal situation (Šubová, 2010). This honorific category takes the form of verb, copula, adjective and a form of modality (Shibatani in Jakobsson, 2016, p.11). 


\section{Aisya Novita Sari \& Zamzani}

Meanwhile, in English, honorifics are often associated with politeness. Honorific and some other deictic term have been recognized as one important mode of politeness (Brown, Winter, Idemaru, \& Grawunder, 2014). Politeness in interaction, based on Yule (1996, p. 60), means using words that show that he/she (the speaker) has 'awareness' with the people he/she is talking to. Green in Thomas $(1995$, p. 178) also explains that when someone talks to other people, he/she makes efforts that are in the option of 'offering options' or 'showing respect'. That act, Green defines it as an act of politeness.

In politeness, there are two types of strategy. The two types of strategy are positive and negative politeness strategies. A positive politeness strategy is a strategy in which a speaker uses or chooses words carefully considering his goals. This means that speakers, in their mind, think they have no high probability of success. However, there are also cases where a speaker uses a 'familiar' strategy when speaking, such as a close friend of the other person he is talking to. Meanwhile, negative politeness strategies are usually in the form of questions that can contain expressions of apology, asking permission, talking at length, and words that show doubt from the speaker (Yule, 1996, p.64).

As stated earlier, when talking to other people a person has an option called 'showing respect'. Yule (1996, p.60) provides example of two different sentences as follows.

(1) Excuse me, Mr. Buckingham, but can I talk to you for a minute?

(2) Hey, Bucky, got a minute?

The two sentences above have the same purpose, which is to talk to a person named Buckingham. However, the two sentences have different impression. The second sentence tends to be informal and impolite. Based on this, we can know that a speaker and a person named Buckingham have a close relationship so that the speaker does not feel obliged to pay respect to the interlocutor. Meanwhile, in the first sentence the speakers tend to use language that is more polite and longer and by using the greeting 'Mr'. This shows that the speaker feels that a person named Buckingham is someone he/she needs to respect so he/she shows politeness when talking to him.

In another cases, honorific which commonly tends to be polite give a vibe that the speaker and the listener is not in close relationship. Okamoto (1999) said that case, the use of honorific, can be means rude. What the meaning of 'rude' here is insincere, too distant, or too deferential. However, the use of honorific can be means as rude, Okamoto said, is depending to the speaker and the situation. It can be assumed that, for example, when a close friend use honorific even when in their usual conversation did not use honorific, it can mean that the meaning of honorific that is used is rude.

Based on the discussion about honorifics above, it can be concluded that honorifics in English tend to have characteristics that the speaker or the person speaking uses language that seems polite to the person spoken to or the speaker. In this study, researchers examine the honorific translation strategy in the subtitles of the film The 
Boss Baby in Indonesian translation. Researchers use the translation strategy proposed by Molina \& Albir.

\section{RESEARCH METHODOLOGY}

Sudaryanto in Mahsun (2014, p. 18) suggests that data are mainly the research object that combined with the context. To deepen the understanding about data, we need to know about research object and research subject. According to that, we can say that the object of the research is the main topic to be analyzed in the research. On the other hand, the subject is exactly the subject of the research, where the researcher gets the data to be analyzed. The subject in this research is the film The Boss Baby. The data or the object of this research is the translation of honorific in English to Indonesian language. In collecting data, this research uses observation method since the researcher needs to scrutinize the data (Sudaryanto, 2015, p. 202) by using noting technique. Thus, in collecting the data, the researcher will watch the film, note the honorific term in its English to Indonesian translation. After noting the needed data, the researcher writes it down in data card. The instrument of this research is human instrument which means that the researcher used the researcher's knowledge, mainly, related to translation, translation strategies, sociolinguistic, and honorific to analysis the presented data. In analyzing the data, the study used identity method (Sudaryanto, 2015 , p. 15) since this study is related to translation, translation strategies, sociolinguistic, and honorific. In analyzing the data the researcher describes the translation strategies of the presented data. The following is the researcher will explain the reason why the chosen translation strategi(es) used and the use of the honorific in the presented data. And lastly, the researcher will make conclusion related to the analysis of the given data.

\section{FINDINGS}

\subsection{A Brief View of the Findings}

Based on the findings, the researchers concluded that here are six types of honorific translation strategies in the film The Boss Baby. The six types are literal translation, naturalization, generalization, reduction, transposition, and linguistic compression.

The findings divided into six subs of six types honorific translation strategies. The summary of the findings is presented in the table below.

Table: 1 The Summary of the Findings

\begin{tabular}{lll}
\hline Translation Technique & Quantity & Percentage \\
\hline Literal translation & 7 & $36,85 \%$ \\
Naturalized & 2 & $10,52 \%$ \\
Generalization & 4 & $21,05 \%$ \\
Reduction & 3 & $15,79 \%$ \\
Transposition & 1 & $5,27 \%$ \\
Linguistic compression & 2 & $10,52 \%$ \\
\hline Total & $\mathbf{1 9}$ & $\mathbf{1 0 0 \%}$ \\
\hline
\end{tabular}

Indonesian Journal of EFL and Linguistics, 5(2), 2020 


\subsection{Findings}

The section discusses the results or findings from the research that has been done. Here, the researcher discuss in detail the findings of the honorific and its translation in the film The Boss Baby. The abbreviation of ST means as source text and TT means as target text. In these findings, it will be divided into six sub-points.

\subsubsection{The Translation of Honorific in the Film The Boss Baby in Literal Translation Strategy}

In the film The Boss Baby there are several honorifics that are used. The following are samples of honorific translation with a literal translation strategy in Indonesian translation as well as a discussion of the honorifics.

(1)

\begin{tabular}{|l|l|}
\hline ST: & Yes, Mr. Francis? \\
\hline TT: & Ya, Tn. Francis ? \\
\hline
\end{tabular}

(00:02:41-00:02:43)

From the data above, it can be seen that the translator uses a literal or word-for-word translation strategy. Molina and Albir (2002) define literal translation as word-forword translation. This can be seen in the word and text structure that does not change from the source language to the target language, such as in 'yes' which is translated as ' $y a$ ' and ' $M r$ ' word which is translated by ' $T n$ '. In the data above, the speaker shows that he has respect for a person named Francis who is the boss of the speaker. This form of honorific can be categorized as titles and ranks. In this case, the greeting ' $\mathrm{Mr}$ ' by the speaker is a sign of respect to his boss. According to Azizah (2017) titles and ranks are usually used to indicate an ordinary (intermediate) or official social relationship if the position or profession of the interlocutor is known. In the example in the data above, the speaker adds the name after the greeting. The use of titles and ranks with the addition of the last name is used when the relationship between the speaker and the speech partner is not that close or older than the speaker. In this case, the speaker uses an additional name because it maintains a hierarchy in the office, which means that the speaker has a lower position than the interlocutor.

(2)

\begin{tabular}{|l|l|}
\hline ST: & Hello? No, ma'am, not yet. \\
\hline TT: & Halo? Belum, Bu. \\
\hline
\end{tabular}

(00:13:01-00:13:03)

(3)

\begin{tabular}{|l|l|}
\hline ST: & Yes, ma'am. I know I've been here a long time. \\
\hline TT: & Ya, Bu, aku tahu aku sudah lama di sini \\
\hline
\end{tabular}

(00:13:06-00:13:09)

In the two data above, the translator uses literal translation strategy because, as has been said in the previous discussion, there is no change in structure and meaning in the translation. In the two data mentioned above, the speaker shows respect for their superiors. This respect can be seen from the use of the word ' $m a$ 'am' which is used by 
speaker. The use of this honorific term is in line with the meaning given by Shalihah (2018), that the honorific term related to title can be used to show the speaker's respect for the interlocutor based on the degree level between the two speakers. This is also the same in the target language which has such a concept that the translator is translated with literal strategy.

(4)

\begin{tabular}{|l|l|}
\hline ST: & Thank you all for coming here on such short notice. \\
\hline TT: & Terima kasih sudah datang dengan pemberitahuan singkat. \\
\hline
\end{tabular}

(00:19:38-00:19:41)

Based on the data above, it can be seen that the speaker shows that he is honored that 'you all' or the people the speaker is talking to can attend a "meeting" even though the notification seems sudden. In this data, the speaker is known to have a higher position than the interlocutor. The speaker realizes that, honorifically, the speaker has a higher power or status than the interlocutor. This gives the understanding that the speaker does not need to give special honorific mention to the interlocutor. Meanwhile, the translation strategy used by the translator from the data is a literal translation strategy because the translator translates the sentence word for word. This literal translation is the same as Nida's formal ekuivalent but not the use of the equivalent which is already the formal form.

(5)

\begin{tabular}{|l|l|}
\hline ST: & Yes, sir! \\
\hline TT: & Ya, Pak! \\
\hline
\end{tabular}

$(00: 19: 45-00: 19: 45)$

The data above is included in the category of literal translation strategies becau se the translator translates the sentence word for word and without any change in structure. The speakers in the data above have a lower position than the interlocutors. Therefore, he respects his interlocutor with the firmness of 'sir' answer as proof that he agrees with what his superior says.

(6)

\begin{tabular}{|l|l|}
\hline ST: & Ticket please. \\
\hline TT: & Tolong tiketnya. \\
\hline
\end{tabular}

$(01: 04: 18-01: 04: 19)$

Based on the data above, it can be seen that the translation strategy used is the literal translation strategy. There is no significant difference between the source language and the target language. The above utterance was spoken by an officer at an airport. Therefore, the officer needs to use polite words to customers or prospective passengers at the airport.

(7)

\begin{tabular}{|l|l|}
\hline ST: & Excuse me, ladies. \\
\hline TT: & Permisi, nona-nona. \\
\hline
\end{tabular}

(01:08:21-01:08:22) 
The data above is included in the category of literal translation strategy. The sentence is translated word for word such as 'excuse me' which is translated 'permisi' and 'ladies' which is translated to 'nona-nona'. Tim said the sentence above to ask for help from several ladies. The younger Tim asked questions with the aim of asking for help, using words that were polite to the ladies in question.

\subsubsection{The Translation of Honorific in the Film The Boss Baby in Naturalized Translation Strategy}

The following is an honorific translation with a naturalization translation strategy in Indonesian for the film The Boss Baby.

(8)

\begin{tabular}{|l|l|}
\hline ST: & Can the baby come, too? \\
\hline TT: & Bayinya boleh ikut ? \\
\hline
\end{tabular}

(00:42:25-00:42:26)

Based on the data above, the translator uses the naturalized translation strategy contained in the word 'baby'. The word 'baby' is translated as the word 'bayi' which has high similarities. The translator translates the word as naturally as possible as the source language. This speech was uttered by Tim who asked or begged his parents so that his younger brother, 'baby', could join Tim and his parents to PuppyCo.

(9)

\begin{tabular}{|l|l|}
\hline ST: & On it, boss. \\
\hline TT: & Segera, bos. \\
\hline
\end{tabular}

$(00: 56: 27-00: 56: 28)$

Based on the data above, it can be seen that the translator uses the naturalized translation strategy contained in the word 'boss' which is then translated as 'bos'. The word 'boss' and the translation of 'bos' have similarities in the pronunciation in English and Indonesian language and the writing of the word. It's just that in the target language the word 'boss' has only one letter ' $s$ ' compared to the word in English. The above utterance was spoken by Staci, a subordinate of Boss Baby. He gave an answer to what his superior, boss, had ordered, in this case Boss Baby.

\subsubsection{The Translation of Honorific in the Film The Boss Baby in Generalization Translation Strategy}

The following is an honorific translation with a generalization translation strategy in Indonesian for the film The Boss Baby.

(10)

\begin{tabular}{|l|l|}
\hline ST: & All right, gentlemen. Welcome to Puppy Co. \\
\hline TT: & Baiklah, semuanya. Selamat datang di Puppy Co. \\
\hline
\end{tabular}

$(00: 43: 10-00: 43: 14)$

In the above utterance, the translator uses the generalization translation strategy contained in the word 'gentlemen', which is translated into 'semuanya'. The word 364

Indonesian Journal of EFL and Linguistics, 5(2), 2020 
'gentlemen', which has a specific meaning intended for men, is translated into 'semua' that has a meaning for male and female. Therefore, the translator can be said to use a more general word in his translation or to use a generalization strategy. The above utterance was spoken by someone who works at a company called PuppyCo. He is in charge of welcoming people who come to the company. For that reason, he used sentences that sounded polite to respect the people who came. Molina and Albir (2002) explain that generalization techniques are techniques for using more general or neutral terms in the target language. Newmark (2001, p. 82) expresses it as neutralization and translation by neutral / less expressive and translation by general words (Baker, 2018, p. 36).

(11)

\begin{tabular}{|l|l|}
\hline ST: & $\begin{array}{l}\text { Ladies and gentlemen, and those in coach... please fasten your seat belts. } \\
\text { We're about to take off. }\end{array}$ \\
\hline TT: & $\begin{array}{l}\text { Para penumpang, dan yang di kelas ekonomi... kencangkan sabuk } \\
\text { pengaman. Kita akan lepas landas. }\end{array}$ \\
\hline
\end{tabular}

$(01: 05: 00-01: 05: 05)$

(12)

\begin{tabular}{|l|l|}
\hline ST: & Ladies and gentlemen, Captain Ross again. \\
\hline TT: & Para penumpang, ini Kapten Ross lagi. \\
\hline
\end{tabular}

$(01: 05: 32-01: 05: 34)$

(13)

\begin{tabular}{|l|l|}
\hline ST: & $\begin{array}{l}\text { Ladies and gentlemen, and those in coach... on the left side of the plane... } \\
\text { you can see we're approaching fabulous Las Vegas. }\end{array}$ \\
\hline TT: & $\begin{array}{l}\text { Para penumpang, dan yang di kelas ekonomi... di sisi kiri pesawat... anda } \\
\text { bisa lihat kita mendekati Las Vegas yang indah. }\end{array}$ \\
\hline
\end{tabular}

$(01: 07: 33-01: 07: 40)$

Based on the three data above, there is a similarity in the translation of the words 'ladies and gentlemen' which are translated with 'para penumpang'. The word 'ladies and gentlemen' means 'ladies' and 'gentlemen'. However, in the translation, the translator does not use this vocabulary. The translator provides the more general words in his translation, namely all of them or 'para penumpang'. Based on this, the translator uses a generalization translation strategy or uses a more general vocabulary (Molina \& Albir, 2002). The utterances mentioned above are used by an airplane pilot who gives directions on the first utterance, greeting in the second utterance, and announcements that sound relaxed in the third utterance. Since all of these utterances were aimed at his passengers, he tended to use polite words to honor his passengers.

\subsubsection{The Translation of Honorific in the Film The Boss Baby in Reduction Translation Strategy}

The following is an honorific translation with a reduction translation strategy in Indonesian for the film The Boss Baby. 
(14)

\begin{tabular}{|l|l|}
\hline ST: & Can you put your head back on, please? \\
\hline TT: & Bisa pakai kembali kepalamu? \\
\hline
\end{tabular}

$(00: 48: 46-00: 48: 48)$

Based on the data above, it can be seen that there are words that have been omitted or reduced in translation. The word is the word ' $y o u$ ' which means 'kamu' in the target language. As for the word 'please' which means a request or has the equivalent of the word 'tolong' is not written in the translation. Due to this, it can be said that the translator uses a reduction or reduction translation strategy by reducing these words in his translation. Tim said the above words to someone who was older than him. Therefore, Tim used words that sounded polite to the other person. This is in accordance with the meaning of reduction translation that this technique implies information because the meaning components are included in the target language. This reduction technique is in line with what Newmark (2001, p. 90) proposes in his book. Baker, (2018, p. 36) states that reduction translation is translation by omissian words or expressions.

(15)

\begin{tabular}{|l|l|}
\hline ST: & Well, can I get you special guys anything? \\
\hline TT: & Kalian mau pesan sesuatu ? \\
\hline
\end{tabular}

Based on the data above, it can be seen that the translator uses a reduction or reduction translation strategy. The words that are reduced in the utterance are the words 'well' and 'you special'. The word well means 'baiklah' and 'you special' means 'kamu' which is 'istimewa' in the target language. Meanwhile, a flight attendant said on a flight to Tim and Boss Baby. The flight attendant considers Tim and Boss Baby to be the children of his boss, Captain Ross. Therefore, the flight attendants used more polite words to them even though they were far below their age.

(16)

\begin{tabular}{|l|l|}
\hline ST: & Can we get a ride home? \\
\hline TT: & Boleh menumpang pulang? \\
\hline
\end{tabular}

(01:08:23-01:08:24)

The word ' $w e$ ' in the above utterance has ' $k a m i$ ' meaning in the target language. However, in the translation, the translation is not written down. Due to this, the translation strategy used by the translator is a reduction or reduction translation strategy. On the other hand, these remarks were uttered by Tim to several ladies he met in Las Vegas. Tim wanted to ask the ladies for help to take him somewhere. Therefore, he uses sentences that are more polite and polite in that context. 


\subsubsection{The Translation of Honorific in the Film The Boss Baby in Transposition Translation Strategy}

The following is an honorific translation with a transposition translation strategy in Indonesian for the film The Boss Baby.

(17)

\begin{tabular}{|l|l|}
\hline ST: & On it, boss. \\
\hline TT: & Segera, bos. \\
\hline
\end{tabular}

(00:56:27-00:56:28)

Based on the data above, there is the word ' $o$ it' which is translated 'segera' into the target language. The word ' $o n$ it' itself has the meaning of being in progress or being worked on. However, in the translation there is a quite different change, however, it still has the same meaning. The word 'on' is an adjective. Meanwhile, the word 'segera' is an adverb. Therefore, the translation strategy in these utterances is transposition or changes in grammar. On the other hand, these words are spoken by Staci to Boss Baby. Since Staci is Boss Baby's subordinate, Staci uses words that sound more respectful to her boss. Transposition is a technique that changes the grammatical category. Transposition technique can also be called as category replacement technique in grammar or shifting categories, structures and units.

\subsubsection{The Translation of Honorific in the Film The Boss Baby in Linguistic Compression Translation Strategy}

The following is an honorific translation with a strategy of translating linguistic compression in Indonesian in the film The Boss Baby.

(18)

\begin{tabular}{|l|l|}
\hline ST: & Is that you, boss? \\
\hline TT: & Kaukah itu, bos? \\
\hline
\end{tabular}

(00:56:23-00:56:24)

In the above data, the translator uses a linguistic compression translation strategy. This can be seen in the word ' $i s$ ', to be in English, which is in front of the interrogative sentence which is interpreted as the suffix word ' $-k a h$ '. The word ' $i s$ ' in front of the interrogative sentence has 'apakah' meaning in the target language. However, in the translation the translator only includes the suffix ' $-k a h$ ' as a substitute or short term for 'apakah'. This is then combined with the translation of the word ' $y o u$ ', namely ' $k a m u$ ' or ' $k a u$ ' so that the translation becomes ' kaukah'. These words were spoken by Staci, a subordinate of the Baby Boss. Since Staci is a subordinate, he tends to use more polite words to his boss or superior.

(19)

\begin{tabular}{|l|l|}
\hline ST: & Would Timothy Templeton please pick up the white courtesy phone? \\
\hline TT: & Timothy Templeton diminta mengangkat telepon putih. \\
\hline
\end{tabular}

(01:02:31-01:02:34)

Indonesian Journal of EFL and Linguistics, 5(2), 2020 
Based on the data above, it can be seen that the translator uses a linguistic compression translation strategy. Kompresi Linguistik (linguistic compression) menurut Molina dan Albir (2002) menjelaskan bahwa teknik ini mensintesis elemen linguistik yang ada menjadi lebih sederhana karena sudah dapat dipahami. This can be seen in the word 'would' which is not translated into the target language. The sentence changes from the question word in the source language to a declarative sentence in the target language. This speech was uttered by airport officials who asked Tim to pick up the telephone at the airport. Since he was an officer, he was required to use polite sentences to everyone at the airport.

\section{DISCUSSION}

The purpose of the present study is to find the translation technique used in translating honorific. The translation technique study is somehow a common study in translation research field. According to Hatim and Mason (1997, p. 1), translation is the process of rendering the communication across different cultural and language background by considering the objectives of the communication toward the target reader. However, the translation of honorific is not commonly conducted. The translation of honorific conducted, for example, like a research conducted by Sukaesih, Nababan, Santosa, and Djatmika (2019) which is related to the translation technique of honorific marker. In their research the most used translation technique used is variation. It is different from the researchers' findings which mostly dominated by literal translation. The literal translation only has a few and its so far different in total from variation technique.

There is also a study of translation and honorific expression in a novel. It was written by Zaman, Nababan, and Djatmika (2018). It focuses on addressee honorific. The findings found that commonly it use adaptation as the technique for translating. Moreover, it also used borrowing technique. However, it is not as common as adaption.

In reduction translation strategy of honorific term in this research, it has similarity with Khristianto's research (2014) specifically in the part 'kesopanan honorifikterlesap ' or the honorific term which is reduced in a translation. In some of the sample data, the honorific term for grandfather that is ' kakek' or short calling 'kek' and short calling 'yang' in its Javanese language, there is no translation in its English language. In this research, however, the findings are not in the form of short calling or short term. For addition, the reduction translation strategy is similar to ellipsis as proposed by Wei and $\mathrm{Yu}$ (2019) about coherence strategies in the translation of scientific texts as the strategy is by omitting certain words.

Moreover, in a case of generalization translation strategy, some terms generalized and become one term like the honorific translation of 'ladies and gentlemen' which translated into 'para penumpang' in the analysis. The conjunction 'and' which divide two different terms come as one in 'para penumpang'. However, the terms sometimes did not need added conjunction like in 'my eyes' which is generalized as ' $a k u$ ' in 
Hidayat's research (2020). The term similar to the translation of 'gentlemen' this translated into 'semuanya' in the analysis.

Other relevant research regarding honorifics was conducted by Pangestu (2018) with the title Max Lane's Indonesian-english honorifics translation of Pramoedya Ananta toer's rumah kaca. Researchers want to know the most widely used strategies for honorific translation in translated novels. Based on the research results, there are 120 honorifics in translated novels. Localization is the most widely used strategy in translating honorifics in novels. On the other hand, in this study, the most widely used strategy is literal translation. This gives a different assessment of the quality of the translation. According to Pangestu, that academic, army, and royal honorifics are better localized when the equal relevance can be found.

Different the case with Fitriani (2014), in her research, it was found that the borrowing strategy is the most dominant strategy and makes the translation results more acceptable so that the target readers feel the same atmosphere as the native readers. Rochmawan (2018) added that in analysing the translation, the analyst should be aware of the ideologies embedded on the text which can change the meaning as the result of different ideologies.

In other hand, Nisaa' (2011) who also research about transposition strategy in films stated the results that the transposition strategy was the most widely used technique. Transposition is a translation technique that is carried out by changing the word order or shifting the category or lingual unit. This is clearly different from the results of the research in this study which found that literal techniques are the most widely used techniques for translating honorifics. It can be understood that in the translation of each aspect there can be differences in the chosen translation technique. In Sujarwanto study (2014) about cultural terms, the results show that the most widely used technique for translating cultural terms is omission strategy. It is different with this study about honorific terms which results in literal translation as the mostly used technique in translating.

\section{CONCLUSION}

Based on the findings and discussion, the dominated translation technique used in the translation of honorific is literal translation. However, it is not like the other technique is rarely used since the gap of the number is not that big. As the discussion about the translation technique of honorific, the translation technique can be in many ways which is not demanded to be the same even if it is about the same aspect of linguistics.

\section{REFERENCES}

Agha, A. (1998). Stereotypes and registers of honorific language. Language in Society, 27(02), 151-193. https://doi.org/10.1017/s0047404598002012

Ahdillah, M. Z. I., Hartono, R., \& Yuliasri, I. (2020). English - Indonesian translation of idiomatic expressions found in the Adventure of Tom Sawyer: Strategies used 
and resulted equivalence. English Education Journal, 10(4), 482-494.

Azizah, A. S. (2017). Analisis Penggunaan Bentuk Sapaan Di Pondok Pesantren AlMuayyad Surakarta. Cita Ilmu, 25(8), 23-34.

Brown, L., Winter, B., Idemaru, K., \& Grawunder, S. (2014). Phonetics and politeness: Perceiving Korean honorific and non-honorific speech through phonetic cues. Journal of Pragmatics, 66, 45-60. https://doi.org/10.1016/j.pragma.2014.02.011

Fadhillah, N., Lubis, M. H., Sinar, T. S., \& Setia, E. (2019). Translation strategies used in Indonesian translation of Acehnese poem "Munajat Perempuan Sufi Aceh Pocut di Beutong." International Journal of Innovation, Creativity and Change, 9(4), 172-182.

Feely, W., Hasler, E., \& de Gispert, A. (2019). Controlling Japanese honorifics in English-to-Japanese neural machine translation. Proceedings of the 6th Workshop on Asian Translation, 45-53. https://doi.org/10.18653/v1/d19-5203

Fitriani C. N. (2014). A Translation Analysis of Address Terms of Negeri 5 Menara in the Land of Five Towers. S1 Thesis. Universitas Negeri Yogyakarta

Haugh, M., \& Obana, Y. (2011). Politeness in Japan. ResearchGate

Hendra. (2019). Translation strategy on "Let It Go" songs that was sung by Idina Menzel with Indonesian version. Journal of English Language Teaching and Literature (JELTL), 2(2), 101-109.

Hidayat, A. (2020). Penerjemahan harfiah: dominasi dalam teknik penerjemahan surat informal. Wanastra: Jurnal Bahasa Dan Sastra, 12(1), 43-49. https://doi.org/10.31294/w.v12i1.7596

Holmes, Janet. (2013). An Introduction to Sociolinguistics: Fourth Edition. New York: Routledge

IMdb. (2017). The Boss Baby (2017). Retrieved from https://www.imdb.com/title/tt3874544/

Irvine, J. T. (1992). Ideologies of honorific language. PragmaticsPragmatics. Quarterly Publication of the International Pragmatics Association (IPrA), 2(3), 251-262. https://doi.org/10.1075/prag.2.3.02irv

Jakobsson, L. (2016). (im)Politeness and Honorification in Japanese Translation. Bachelor Thesis in Lund University, Centre for Languages and Literature

Khristianto. (2014). Saat kesopanan melintas batas: ulasan teks terjemahan multibahasa dari perspektif sosiopragmatik. Prosiding Prasasti, 104-109.

Kridalaksana, Harimurti. (2011). Kamus Lingusitik: Edisi Keempat. Jakarta: Kompas Gramedia

Mahsun. (2014). Metode Penelitian Bahasa. Jakarta: Rajawali Pers

Mansor, N. S., Abd Rahim, N., Mamat, R., \& Abdul Halim, H. (2018). Understanding the choices of terms of address: a sociolinguistic study of Malay cultural practices. Indonesian Journal of EFL and Linguistics, 3(2), 129-147. https://doi.org/10.21462/ijefl.v3i2.76

Manullang, E. B., \& Marpaung, G. H. (2020). Translation Strategy in Toba Dream movie subtitle. Jurnal Darma Agung, 28(2), 299-306. https://doi.org/10.46930/ojsuda.v28i2.651 
Molina, L., \& Albir, A. H. (2002). Translation techniques revisited: A dynamic and functionalist approach. Meta, 47(4), 498-512. https://doi.org/10.7202/008033ar

Munday, J. (2016). Introducing translation studies: theories and applications (fourth edition). New York: Routledge

Nababan, D. J. (2007). Metode, strategi, dan teknik penerjemahan: sebuah tinjauan mendalam. Masyarakat Linguistik Indonesia (Kumpulan Makalah Ringas Kongres LinguistikXII), 12, 43-56.

Newmark, Peter. (1988). A Textbook of Translation. New York: Prentice Hall

Newmark, P. (2001). Approaches to translation. Oxford: Pergamon Press

Nisaa, R. K. (2011). Analisis teknik, metode, dan ideologi penerjemahan subtitle film Beckham Unwrapped dan dampaknya pada kulitas terjemahan. Thesis. Universitas Sebelas Maret

Okamoto, S. (1999). Situated Politeness : manipulating honorific and non-honorific. Pragmatics, 9(1), 51-74.

Pangestu, P. D. (2018). Max Lane'S Indonesian-English Honorifics Translation of Pramoedya Ananta Toer's Rumah Kaca. Thesis. Universitas Sanata Dharma

Qiuyang, W., \& Yingli, W. (2020). Translation strategies in the context of international exchange and cooperation in colleges: on subtitle translation of titanic from relevance theory. Advances in Social Science, Education and Humanities Research, 451, 127-129. https://doi.org/10.2991/assehr.k.200727.076

Rahayu, E. T., \& Fauzan, A. (2020). The language choice as a reflection of Islamic communication in The Quran-Japanese translation. Madania: Jurnal Kajian Keislaman, 24(1), 73-82. https://doi.org/10.29300/madania.v24i1.3073

Salsabila, R., \& Jumanto, J. (2020). Translation strategies for cultural expressions in Garuda Indonesia's inflight magazine "Colors." Jurnal Basis, 7(1), 185-198. https://doi.org/10.33884/basisupb.v7i1.1899

Sambayu, H. (2019). Metaphorical translation strategies of bahasa indonesia into english on contemporary Indonesian poetry translated by Harry Aveling. Jurnal Pionir LPPM Universitas Asahan, 5(2), 37-41.

Shalihah, M. (2018). A pragmatic analysis on the types and the purposes of address terms used by the main character in Jane Austen's "EMMA". EnJourMe, 3(2), 52-60. https://doi.org/10.26905/enjourme.v2i2.2747

Šubová, M. (2010). Addressing Across Culture. V Olomouci 16. srpna

Subscene. (2017). The Boss Baby. Retrieved from https://subscene.com/subtitles/theboss-baby/english/1590368

Subscene. (2017). The Boss Baby. Retrieved from https://subscene.com/subtitles/theboss-baby/indonesian/1590529

Sudaryanto. (2015). Metode dan Aneka Teknik Analisis Bahasa: Pengantar Wahana Kebudayaan secara Linguistis. Yogyakarta: Sanata Dharma University Press

Sujarwanto, I. R. (2014). Foreignization and Domestication Ideologies in the Translation of Indonesian Culture-Spesific Items of Rambe's Mirah dari Banda into Pollard's Mirah of Banda. S1 Thesis. Universitas Negeri Yogyakarta

Sukaesih, I., Nababan, M. R., Santosa, R., \& Djatmika, D. (2019). Accidentally Rude: 
A study on translation techniques of a translated english-sundanese novel. Advances in Social Science, Education and Humanities Research, 254, 165-168. https://doi.org/10.2991/conaplin-18.2019.34

Tanjung, Sufriati. (2018). Penialain Penerjemahan Jerman-Indonesia. Yogyakarta: Kanwa Publisher

Thomas, Jenny. (1995). Meaning in Interaction: An Introduction to Pragmatics. New York: Taylor\&Francis

Vinay, J., \& Darbelnet, J. (1995). Comparative Stylistics of French and English (A metodology for translation). Amsterdam: John Benjamins Publishing Company

Volkova, T. (2014). Translation Model, Translation Analysis, Translation Strategy: An Integrated Methodology. Procedia - Social and Behavioral Sciences, 154(October), 301-304. https://doi.org/10.1016/j.sbspro.2014.10.167

Wei, M., \& Yu, G. (2019). On the Characteristics of Scientific Discourse and Translation. Theory and Practice in Language Studies, 9(8), 946. https://doi.org/10.17507/tpls.0908.08

Yang, C. (2010). Translation of English and Chinese Addressing Terms from the Cultural Aspect. Journal of Language Teaching and Research, 1(5), 738-742. https://doi.org/10.4304/jltr.1.5.738-742

Yule, George. (1996). Pragmatics. Oxford: Oxford University Press

Zaman, M. N., Nababan, M. R., \& Djatmika, D. (2018). Translation Study of greetings and verbs in accommodating honorific expressions of Okky Madasari novels. Jurnal Pendidikan: Teori, Penelitian, dan Pengembangan, 3(4), 528 - 537 